\title{
PEMBENTUKAN KELOMPOK SADAR WISATA ( POKDARWIS ) DAN PENGEMBANGAN WISATA DI PANTAI GEMAH
}

\section{FORMATION OF TOURISM AWARENESS GROUPS (POKDARWIS) AND TOURISM DEVELOPMENT AT GEMAH BEACH}

\author{
Laily Purnawati \\ Fakultas Ilmu Sosial dan Ilmu Politik Universitas Tulungagung, Tulungagung, Indonesia. \\ lailypurnawatisip@gmail.com
}

\begin{abstract}
ABSTRAK
Devisa terbanyak bagi daerah disumbangkan oleh bidang pariwisata. Hal ini disebabkan karena Indonesia memiliki keanekaragaman Potensi wisata. Salah satunya di Tulungagung terdapat Pantai yang sudah dikenal oleh wisatawan dan wisatawan sudah banyak yang berkunjung,yaitu Pantai Gemah. Destinasi tersebut dikelola oleh Kelompok Sadar Wisata "Lejar Misuwur" yang bertugas mengelola dan mengembangkan Potensi Wisata Pantai Gemah Tulungagung sehingga menjadi Destinasi Wisata yang Layak Jual. Dengan adanya Pokdarwis ini diharapkan mampu menambah minat wisatawan baik lokal maupun nasional untuk mengunjungi pantai Gemah karena objek wisata sudah dikelola dengan sangat baik oleh kelompok Pokdarwis Lejar Misuwur tersebut.

Bagaimana pengembangan obyek wisata di pantai Gemah Tulungagung melalui pembentukan Pokdarwis dan Faktor pendukung dan penghambat apa saja dalam pelaksanaan pengembangan pariwisata di pantai Gemah Tulungagung merupakan rumusan masalah yang akan diteliti dalam penelitian ini. Tujuan penelitian ini adalah untuk menganalisa dampak pembentukan kelompok sadar wisata bagi pengembangan pariwisata di pantai gemah beserta faktor pendorong dan penghambat di dalamnya.

Untuk menganalisa hasil penelitian peneliti menggunakan pendekatan deskriptif kualitatif. Dimana pengumpulan data dilakukan dengan metode wawancara, observasi, dan dokumentasi. Subjek penelitian adalah pengurus, anggota Pokdarwis Lejar Misuwur, masyarakat Desa Keboireng dan, Pengunjung Pantai Gemah. Pembuktian keabsahan data menggunakan teknik triangulasi sumber. Analisis data yang digunakan adalah analisi kualitatif dengan langkah reduksi data, display data, dan penarikan kesimpulan.

Dengan terbentuknya Pokdarwis di pantai Gemah membawa dampak yaitu wisata pantai Gemah menjadi terkenal di skala nasional. Dengan adanya Pokdarwis, dari sisi pengelolaan sudah mulai baik dan memberikan pengetahuan dan ketrampilan masyarakat disekitar pantai Gemah.
\end{abstract}

Kata Kunci : Pembentukan kelompok sadar wisata,pengembangan pariwisata,Pantai Gemah Tulungagung.

\section{ABSTRACT}

Most of the foreign exchange for the region was contributed by the tourism sector. This is because Indonesia has a diversity of tourism potential. One of them in Tulungagung there is a beach that is already known by tourists and many tourists have visited, namely Gemah Beach. The destination is managed by the Tourism Awareness Group "Lejar 
Misuwur" which is in charge of managing and developing the Tourism Potential of Tulungagung Gemah Beach so that it becomes a Tourism Destination Worth Selling. With this Pokdarwis, it is hoped that it will increase the interest of both local and national tourists to visit Gemah beach because the tourist attraction has been managed very well by the Lejar Misuwur Pokdarwis group.

How is the development of tourism objects on Gemah Tulungagung beach through the formation of Pokdarwis and what supporting and inhibiting factors in the implementation of tourism development on Gemah Tulungagung beach is the formulation of the problem that will be examined in this study. The purpose of this study was to analyze the impact of forming a tourism awareness group for tourism development in Panati Gemah along with the driving and inhibiting factors in it.

To analyze the research results, the researcher used a qualitative descriptive approach. Where data collection is done by interview, observation, and documentation. The research subjects were administrators, members of the Lejar Misuwur Pokdarwis, the people of Keboireng Village and, visitors to Gemah Beach. Proof of data validity using source triangulation technique. Analysis of the data used is a qualitative analysis with data reduction steps, data display, and drawing conclusions.

With the formation of Pokdarwis on Gemah beach, it had an impact, namely Gemah beach tourism became famous on a national scale. With the existence of Pokdarwis, in terms of management, it has started well and has provided knowledge and skills to the community around Gemah beach.

Keywords: Formation of tourism awareness groups, tourism development, Gemah Beach Tulungagung.

\section{PENDAHULUAN}

Pariwisata dipandang sebagai sektor yang dapat mendorong dan meningkatkan kegiatan pembangunan, membuka lapangan usaha baru, membuka lapangan kerja dan dapat meningkatkan pendapatan masyarakat, serta pendapatan asli daerah. Apabila dapat dikelola dan dikembangkan secara maksimal. Indonesia, disamping menyimpan berjuta pesona wisata alam yang begitu indah juga kaya akan wisata budayanya. Kekayaan budaya ini bisa terlihat dari peninggalan- peninggalan sejarah serta keanekaragaman seni adat budaya masyarakat lokal yang menarik wisatawan lokal maupun mancanegara, sehingga dengan banyaknya potensi yang dimiliki menjadikan Indonesia sebagai salah satu daerah tujuan wisata. Keramahan penduduk dan juga beragamnya tempat tujuan wisata di dalam negeri membuat Indonesia seharusnya bisa menjadikan pariwisata sebagai sebuah hal yang bisa dibanggakan. (Dahuri, 2012:329).

Sarana dan prasarana dalam suatu objek wisata itu sangat diperlukan untuk menarik wisatawan untuk mengunjungi suatu objek wisata. Semakin lengkap sarana dan prasarana yang disediakan di suatu objek wisata akan membuat wisatawan nyaman dan betah menikmati objek wisata tersebut. Dalam UU No. 10 Tahun 2009 tentang Kepariwisataan dijelaskan bahwa pariwisata ialah berbagai macam kegiatan wisata dan didukung berbagai fasilitas serta layanan yang disediakan oleh masyarakat, pengusaha dan pemerintah.

Pariwisata merupakan potensi yang luar biasa menarik bagi setiap daerah di Indonesia. Dengan menyajikan pariwisata modern, yang terdapat komponen penting, yaitu : destinasi, transportasi, pemasaran pariwisata dan sumber daya. Dalam perspektif yang lain, Pemerintah Indonesia mengklasifikasikan komponen pariwisata ke dalam beberapa bagian penting seperti;1)industri pariwisata,2)destinasi pariwisata,3) pemasaran pariwisata, dan 4) kelembagaan pariwisata. ( Bungin, 2015:86 ). 


\section{PUBLICIANA : JURNAL ILMU SOSIAL DAN ILMU POLITIK \\ VOLUME 14, NO 02}

ISSN : 1979 - 0295 / E-ISSN : 2502 - 7336

Pengelolaan kegiatan pariwisata sangat diperlukan dalam rangka menahan wisatawan untuk tinggal lebih lama di daerah tujuan wisata dan bagaimana wisatawan membelanjakan uang sebanyak-banyaknya selama melakukan wisata. Makin lama wisatawan berada di suatu tempat wisata akan meningkatkan pengeluaran mereka, sehingga akan membangkitkan perusahan jasa transportasi, hiburan, akomodasi, dan jasa lainnya.

Pengembangan kepariwisataan berkaitan erat dengan pelestarian budaya bangsa, dengan memanfaatkan seluruh potensi keindahan dan kekayaan alam. Pengembangan disini bukan berarti merubah secara total, tetapi lebih berarti mengelola, untuk memanfaatkan dan melestarikan setiap potensi yang ada, dimana potensi tersebut dirangkaikan menjadi satu daya tarik wisata. Oleh karena itu pengelolaan dan memanfaatkan potensi pariwisata yang dimiliki daerah juga dikelola oleh masing-masing daerah. Begitu juga halnya dengan Kabupaten Tulungagung yang memiliki banyak potensi dan sumber daya alam yang dapat dikembangkan sebagai daya tarik wisata.

Sebagai salah satu daerah tujuan wisata, Pemerintah Kabupaten Tulungagung harus mampu membangun serta mengelola kepariwisataannya dengan mengacu pada pariwisata modern, sehingga pariwisata di Tulungagung dapat dilaksanakan secara optimal. Pengembangan obyek wisata ini membutuhkan kerjasama seluruh pemangku kepentingan yang terdiri dari masyarakat dan pemerintah, kerjasama pihak umum maupun dari pihak swasta.

Dalam Peraturan Menteri Kebudayaan dan Pariwisata No. PM.04/UM.001/MKP/2008 Pasal1 dijelaskan bahwa Sadar Wisata adalah suatu kondisi yang menggambarkan partisipasi dan dukungan segenap komponen masyarakat dalam mendorong terwujudnya iklim yang kondusif bagi tumbuh dan berkembangnya kepariwisataan disuatu destinasi atau wilayah. Sedangkan kelompok sadar wisata merupakan salah satu bentuk kelembagaan informal yang dibentuk anggota masyarakat (khususnya yang memiliki kepedulian dalam mengembangkan kepariwisataan didaerahnya).

Suatu daerah tujuan wisata, apabila dikelola dengan baik akan membawa manfaat bagi masyarakat setempat. Masyarakat bisa membuka berbagai usaha seperti toko oleh- oleh maupun jasa pemandu wisata. Hal ini juga dapat dimanfaatkan untuk memperkenalkan produk lokal, misalnya jajanan atau makanan khas agar dapat menjadi ikon suatu daerah. Karena wisata tidak hanya menyuguhkan keindahan alam saja tetapi perlu mengenalkan budaya lokal, serta wisata kuliner sehingga dapat menarik minat wisatawan yang akan berkunjung ke suatu tempat wisata.

Kabupaten Tulungagung merupakan kabupaten yang sangat kaya dengan potensi alam, budaya dan pariwisata. Wisata Bahari menjadi sektor unggulan, karena Kabupaten Tulungagung berbatasan langsung dengan samudra hindia sehingga banyak ditemukan pantai dengan panorama yang menakjubkan sehingga sering dikunjungi wisatawan baik lokal maupun nasional, selain wisata bahari, adapun objek wisata lainnya seperti wisata religi/budaya, ekowisata dan event wisata juga mulai dilirik para wisatawan.

Saat ini, Tulungagung memiliki objek wisata andalan yang menjadi daya tarik bagi wisatawan untuk berkunjung, yaitu Wisata Pantai. Salah satu pantai andalan di Tulungagung saat ini adalah Pantai Gemah. Pantai Gemah terletak di desa Keboireng kecamatan Besuki kabupaten Tulungagung. Perlu waktu kurang lebih satu jam dari pusat kota menuju Pantai Gemah. Akses jalan menuju Pantai Gemah dulunya tidak mudah untuk ditempuh. Karena jarak yang jauh dengan pemukiman warga dan infrastuktur yang belum memadai. 
Namun, setelah adanya pembangunan Jalur Lintas Selatan akses jalan menuju Pantai Gemah tidak perlu dikhawatirkan lagi. Pembangunan tersebut berdampak baik bagi perkembangan wisata di Tulungagung. Hal ini yang kemudian dimanfaatkan oleh Pemerintah Tulungagung untuk mengembangkan potensi wisata di sekitar Jalur Lintas Selatan. Salah satunya adalah Pantai Gemah.

Pantai Gemah memiliki hamparan pasir berwarna kecoklatan, merupakan salah satu pantai yang memiliki garis pantai cukup panjang serta terdapat pohon-pohon cemara di area pinggir pantai. Suasana asri dan alami dari pantai gemah akan menjadi daya tarik sendiri bagi wisatawan. Hal ini jika didukung oleh pemerintah kabupaten Tulungagung serta masyarakat sekitar objek wisata, maka objek wisata akan selalu terjaga keindahannya.

Besarnya potensi wisata yang ada di kabupaten Tulungagung belum dibarengi dengan pengelolaan yang optimal terutama dari masyarakat setempat. Belum semua tempat wisata mempunyai kelompok sadar wisata padahal peran pokdarwis ini sangat penting bagi pengembangan potensi wisata setempat dan untuk menarik minat wisatawan. Hal ini disadari oleh masyarakat di sekitar pantai Gemah atas anjuran dinas pariwisata mereka membentuk kelompok sadar wisata ( Pokdarwis ) dengan nama Lejar Misuwur.

Hingga saat ini, Kelompok Sadar Wisata "Lejar Misuwur" tetap berusaha mencari inovasi baru untuk mengembangkan wisata pantai Gemah. Sehingga pengunjung yang datang bukan penduduk Tulungagung saja, melainkan pengunjung yang berasal dari kota lainnya. Pantai Gemah menjadi sarana wisata yang sesuai dengan kebutuhan keluarga, karena adanya fasilitas yang memadai. Dimulai dari parkiran yang luas, adanya penjual makanan dan minuman, musholla dan toilet serta cindera mata dan menyuguhkan wahana di sekitar pantai. Sehingga, hal ini berdampak baik bagi penduduk lokal, karena mendapatkan peluang usaha untuk meningkatkan kesejahteraan hidup mereka.

Kelompok Sadar Wisata "Lejar Misuwur" adalah kelompok yang bergerak secara swadaya sehingga pengembangan pariwisata yang dilakukan di desa yang bersumber dari kekuatan desa sendiri dengan segala potensinya. Kelompok Sadar Wisata "Lejar Misuwur" terbentuk karena kesadaran masyarakat Desa Keboireng akan adanya potensi wisata yang ada di desa mereka. Kelompok Sadar Wisata "Lejar Misuwur" juga harus membangun dirinya secara swakarsa alias menciptakan pengembangan berdasar potensi kreativitas yang mereka miliki karena mereka memiliki hak atas pengembangan desa dengan segala sumber daya yang dimiliki.

Kelompok Sadar Wisata harus memacu peran dan partisipasi masyarakat dalam membangun potensi wisata yang dimiliki desanya sehingga pengetahuan dan keahlian dalam kepariwisataan warga desa terus berkembang. Dengan demikian pariwisata bisa memberikan kontribusi yang nyata bagi peningkatan ekonomi warga desa. Secara luas, Kelompok Sadar Wisata bertanggungjawab penuh mengenai bagaimana menciptakan manfaat kepariwisataan bagi warga masyarakat (terutama anggota Kelompok Sadar Wisata sendiri) dan secara keorganisasian terus berupaya mensukseskan pembangunan kepariwisataan.(Wijaya et al., 2016).

Komunikasi membantu pemasaran pariwisata di berbagai elemen pemasaran, komunikasi berperan baik di media komunikasi maupun konten komunikasi. Di media komunikasi, tersedia berbagai macam media komunikasi sebagai saluran pemasaran, destinasi, aksesibilitas maupun saluran media Sumber Daya Manusia dan kelembagaan pariwisata. Kelompok Sadar Wisata perlu melakukan strategi dalam memasarkan produk mereka, dalam hal ini produk pariwisata.

Hal tersebut juga disadari oleh pokdarwis "Lejar Misuwur", supaya menjadi obyek wisata yang dapat dikenali oleh wisatawan domestik maupun wisatawan mancanegara 
sejauh ini, Kelompok Sadar Wisata memanfaatkan media dari Tulungagung Tourism yang berisi seputar informasi destinasi wisata yang ada di Tulungagung.

Perkembangan sektor Pariwisata di Indonesia juga dapat dimanfaatkan oleh Kelompok Sadar Wisata sebagai acuan mereka untuk terus mengembangkan pantai Gemah sebagai wisata yang layak untuk dikunjungi wisatawan mancanegara. Perlu adanya stakeholder pariwisata yang digandeng Kelompok Sadar Wisata. Salah satunya dukungan dari Pemerintah, swasta ( biro travel), hotel, penduduk lokal, ataupun Perguruan Tinggi agar dapat mengembangkan wisata Pantai Gemah sebagai destinasi wisata favorit.

Berdasarkan uraian latar belakang di atas, penulis tertarik untuk meneliti tentang bagaimana dampak terbentuknya kelompok sadar wisata ( Pokdarwis ) bagi pengembangan wisata di pantai gemah Tulungagung dan faktor apa saja yang mendukung dan menghambat di dalam pengembangan pariwisata di pantai gemah Tulungagung.

\section{KERANGKA TEORI}

\section{Kelompok Sadar Wisata ( Pokdarwis )}

Kelompok Sadar Wisata (Pokdarwis) adalah kelembagaan ditingkat masyarakat yang anggotanya terdiri dari para pelaku kepariwistaan yang memiliki kepedulian dan tanggung jawab serta berperan sebagai penggerak dalam mendukung terciptanya iklim kondusif bagi tumbuh dan berkembangannya kepariwisataan serta terwujudnya Sapta Pesona dalam meningkatkan pembangunan daerah melalui kepariwisataan dan manfaatkannya bagi kesejahteraan masyarakat sekitar.(Rohyani et al., 2019)

Kelompok ini bersifat informal sebagai wadah bertukar pikiran,kegiatan, pembicaraan dan pengembangan dalam rangka mencapai tujuan agar wilayah di Kabupaten Tulungagung dapat menjadi wilayah yang mempunyai daya tarik wisata. Pembentukan kelompok sadar wisata, sebagai wujud dari konsep pengembangan potensi pariwisata berbasis masyarakat mulai dilakukan pemerintah daerah. Pembentukan pokdarwis ini untuk memberikan pemahaman kepada masyarakat disekitar lokasi pariwisata mengenai pentingnya keterlibatan warga secara langsung dalam menjaga serta mengembangkan objek wisata yang ada di masing-masing wilayah.

Pembentukan kelompok sadar wisata mempunyai maksud mengembangkan kelompok masyarakat yang dapat berperan sebagai motivator, penggerak serta komunikator dalam upaya meningkatkan kesiapan dan kepedulian masyarakat disekitar destinasi pariwisata atau lokasi daya tarik wisata agar dapat berperan sebagai tuan rumah yang baik bagi berkembangnya kepariwisataan, serta memiliki kesadaran akan peluang dan nilai manfaat yang dapat dikembangkan dari kegiatan pariwisata untuk meningkatkan kesejahteraan ekonomi masyarakat.

Dimana tujuan pembentukan pokdarwis adalah sebagai berikut :

1. Meningkatkan posisi dan peran masyarakat sebagai subjek atau pelaku penting dalam pembangunan kepariwisataan,serta dapat bersinergi dan bermitra dengan pemangku kepentingan terkait dalam meningkatkan kualitas perkembagan kepariwisataan didaerah.

2. Membangun dan menumbuhkan sikap dan dukungan positif masyarakat sebagai tuan rumah melalui perwujudan nilai-nilai Sapta Pesona bagi tumbuh dan berkembangnya kepariwisatan didaerah dan manfaatnya bagi pembangunan daerah maupun kesejahteraan masyarakat.

3. Memperkenalkan, melestarikan dan memanfaatkan potensi daya tarik wisata yang ada dimasing- masing daerah.(Tengah, 2020) 
Lingkup kegiatan Pokdarwis yang dimaksud disini adalah berbagai kegiatan yang dapat diprogamkan dan dilaksanakan untuk mewujudkan fungsi dan tujuan pembentukan organisasi Pokdarwis. Lingkup kegiatan tersebut meliputi antara lain :

1) Mengembangkan dan melaksanakan kegiatan dalam rangka peningkatan pengetahuan dan wawasan paraanggota Pokdarwis dalam bidang kepariwisataan.

2) Mengembangkan dan melaksanakan kegiatan dalam rangka peningkatan kemampuan dan keterampilan para anggota dalam mengelola bidang usaha pariwisata dan usaha terkait lainnya.

3) Mengembangkan dan melaksanakan kegiatan untuk mendorong dan memotivasi masyarakat agar menjadi tuan rumah yang baik dalam mendukung kegiatan kepariwisataan di daerahnya.

4) Mengembangkan dan melaksanakan kegiatan untuk mendorong dan memotivasi masyarakat untuk meningkatkan kualitas lingkungan dan daya tarik pariwisata setempat melalui upaya-upaya perwujudan sapta pesona.

5) Mengumpulkan, mengolah dan memberikan pelayanan informasi kepariwisataan kepada wisatawan dan masyarakat setempat.

6) Memberikan masukan-masukan kepada aparat pemerintah dalam mengembangkan kepariwisataan di daerah setempat.(Wijaya et al., 2016)

Dari penjelasan-penjelasan tersebut dapat disimpulkan bahwa kegiatan Pokdarwis meliputi mengembangkan dan melaksanakan kegiatan guna meningkatkan pengetahuan serta wawasan kepariwisataan, meningkatkan kemampuan dan juga keterampilan dalam mengelola sebuah usaha,mengelola dan memberikan pelayanan informasi kepariwisataan kepada wisatawan dan masyarakat,dan juga memberikan sarana atau masukan kepada pemerintah daerah dalam rangka untuk pengembangan pariwisata didaerah tersebut.

Pada hakekatnya kegiatan pembangunan pariwisata sama seperti pembangunan di sector lain. Diperlukan peran dari seluruh pemangku kepentingan yang ada dan terkait. Salah satu pemangku kepentingan yang memiliki peran dan fungsi yang penting adalah masyarakat. Masyarakat dengan sumberdaya yang dimiliki, baik berupa adat, tradisi dan budaya serta kapasitasnya berperan sebagai tuan rumah (host), namun juga sekaligus memiliki kesempatan sebagai pelaku pengembangan kepariwisataan sesuai kemampuan yang dimilikinya.(Anarta, 2019).

Kelompok Sadar Wisata (Pokdarwis) merupakan kelompok swadaya masyarakat yang memiliki kepedulian dalam pengembangan pariwisata di daerahnya. Kelompok Sadar Wisata (Pokdarwis) memiliki peran dan posisi yang penting dalam pengembangan pariwisata diantaranya:

a) Sebagai subyek atau pelaku pembangunan

Sebagai subyek atau pelaku pembangunan, yaitu masyarakat menjadi pelaku penting yang harus terlibat secara aktif dalam proses perencanaan dan pengembangan kepariwisataan, bersama-sama dengan pemangku kepentingan memiliki peran dengan terkait linknya baik dari pemerintah maupun swasta.

b) Sebagai penerima manfaat

Sebagai penerima manfaat berarti bahwa masyarakat diharapkan dapat memperoleh nilai manfaat ekonomi yang berarti dari pengembangan kegiatan kepariwisataan untuk meningkatkan kualitas hidup dan kesejahteraan sosial masyarakat yang bersangkutan. Sehingga dengan adanya Kelompok Sadar Wisata diharapkan kesejahteraan masyarakat dapat meningkat melalui peningkatan perekonomian mereka.

c) Sebagai penggerak dalam menciptakan lingkungan dan suasana yang kondusif 


\section{PUBLICIANA : JURNAL ILMU SOSIAL DAN ILMU POLITIK \\ VOLUME 14, NO 02}

ISSN : 1979 - 0295 / E-ISSN : 2502 - 7336

Salah satu aspek mendasar dalam keberhasilan membangun kepariwisataan adalah dapat diciptakannya lingkungan dan suasana kondusif yang mendorong tumbuh dan berkembangnya kegiatan kepariwisataan disuatu tempat.

d) Mewujudkan Sapta Pesona dalam masyarakat

Sapta pesona adalah unsur penting yang harus diwujudkan bagi terwujudnya lingkungan yang kondusif dan ideal bagi berkembangnya kegiatan kepariwisataan disuatu tempat yang mendorong tumbuhnya minat wisatawan untuk berkunjung. Unsur sapta pesona meliputi: aman, tertib, bersih, sejuk, indah, ramah, dan kenangan. Sebagai salah satu unsure penting dalam mendukung pengembangan destinasi pariwisata tentu tidak dapat terwujud tanpa adanya langkah dan juga upaya untuk merintis, menumbuhkan, mengembangkan dan melaksanakan secara konsisten. Sehingga Kelompok Sadar Wisata sebagai salah satu penggerak dalam masyarakat memiliki peran dalam mewujudkan Sapta Pesona tersebut.(Rohyani et al., 2019)

\section{Pengembangan Pariwisata}

Pengembangan merupakan suatu usaha yang dilakukan secara sadar,terencana dan terarah untuk membuat atau memperbaiki, sehingga menjadi produk yang semakin bermanfaa tuntuk meningkatkan dan mendukung serta meningkatkan kualitas sebagai upaya menciptakan mutu yang lebih baik.

Pariwisata dapat diterjemahkan sebagai sistem yang mengaitkan antara lingkungan fisik, ekonomi, dan sosial budaya, dan industri dalam upaya unntuk memenuhi kebutuhan perjalanan seseorang yang dilakukan keluar lingkungan tempat tinggal atau tempat kerjanya dengan motivasi selain mencari nafkah di tempat tujuannya dan sekaligus mempertimbangkan dampak yang ditimbulkan terhadap alam dan budaya.( Ismayati,2015:3).

Pengembangan pariwisata bertujuan memberikan keuntungan bagi wisatawan maupun warga setempat. Basis pengembangan pariwisata adalah potensi sumber daya keragaman budaya, seni, dan alam (pesona alam). Pengembangan sumberdaya tersebut dikelola melalui pendekatan peningkatan nilai tambah sumber daya secara terpadu antara pengembangan produk pariwisata dan pengembangan pemasaran pariwisata melalui pendekatan pemberdayaan masyarakat lokal dalam rangka pengembangan pariwisata.( Sukiman,2012:53 ).

Pariwisata dapat dibedakan menurut motif wisatawan untuk mengunjungi suatu tempat. Jenis-jenis pariwisata tersebut sebagai berikut:

a) Wisata Budaya

Wisata budaya, yaitu perjalanan yang dilakukan atas dasar keinginan untuk memperluas pandangan hidup seseorang dengan jalan mengadakan kunjungan atau peninjauan ketempat lain atau keluar negeri, mempelajari keadaan rakyat, kebiasaan adat istiadat mereka, cara hidup mereka,budaya dan seni mereka.

b) Wisata Maritim atau Bahari

Jenis wisata ini banyak dikaitkan dengan kegiatan olahraga di air, lebih-lebih di danau, pantai,teluk, atau laut seperti memancing,berlayar, menyelam sambil melakukan pemotretan, kompetisi berselancar, balapan mendayung, melihat-lihat taman laut dengan pemandangan indah dibawah permukaan air serta berbagai rekreasi perairan yang banyak dilakukan didaerah-daerah atau negara-negara maritim.

c) Wisata Cagar Alam 
Jenis wisata ini biasanya diselenggarakan oleh agen atau biro perjalanan yang mengkhususkan usaha-usaha dengan jalan mengatur wisata ketempat atau daerah cagaralam, taman lindung, hutan daerah pegunungan, dan sebagainya yang kelestariannya dilindungi oleh undang-undang.

d) Wisata Konvensi

MICE diartikan sebagai wisata konvensi, dengan batasan:usaha jasa konvensi, perjalanan insentif,dan pameran merupakan usaha dengan kegiatan member jasa pelayanan bagi suatu pertemuan sekelompok orang (negarawan, usahawan, cendekiawan,dansebagainya) untuk membahas masalah-masalah yang berkaitan dengan kepentingan bersama.

e) Wisata Pertanian(Agrowisata)

Agrowisata bagi wisatawan adalah mendidikkan wisatawan untuk memahami kehidupan nyata tentang pertanian dan memberikan pemahaman kepada wisatawan bahwa kehidupan bertani adalah pekerjaan yang amat mulia karena kehidupan manusialainnya sangat tergantung pada pertanian. Keuntungan lain bagi wisatawan adalah mereka dapat menikmati alam yang sehat dan alamiah bebas daripolusi kota, mendapatkan produk pertanian yang benar-benar segar dan bahkan organic atau greenproduct,agrowisata memberikan pengalaman perjalanan wisata yang unik dan merupakan perjalanan wisata yang relative murah jika dibandingkan dengan wisata lainnya.

f) Wisata Buru

Jenis wisata ini banyak dilakukan dinegeri-negeri yang memang memiliki daerah atau hutan tempat berburu yang dibenarkan oleh pemerintah dan digalakkan oleh berbagai agen atau biro perjalanan.

g) Wisata Ziarah

Jenis wisata ini sedikit banyak dikaitkan dengan agama, sejarah,adat istiadat, dankepercayaan. Wisata ziarah banyak dilakukan oleh perorangan atau rombongan ketempat- tempat suci,kemakam-makam orang besaratau pemimpin yang diagungkan,tempat pemakaman tokoh atau pemimpin sebagaiman usia ajaib penuh legenda.(Utama, 2016:144159).

Salah satu hal yang perlu diperhatikan dan mendukung di dalam pengembangan pariwisata suatu daerah adalah adanya sarana dan prasarana kepariwisataan. Sarana kepariwisataan ini muncul ketika ada wisatawan yang berkunjung kesuatu destinasi wisata dan tujuan dari adanya sarana kepariwisataan ini selain untuk memberikan pelayanan terhadap wisatawan juga merupakan cara agar wisatawan betah untuk tinggal lebih lama ditempat pariwisata tersebut.(Junaid et al., 2019)

Sedangkan prasarana kepariwisataan adalah semua fasilitas yang dapat memungkinkan proses perekonomian berjalan dengan lancar sedemikian rupa, sehingga dapat memudahkan manusia untuk dapat memenuhi kebutuhannya .

Menurut Muljadi (2012:13) prasarana kepariwisataan adalah semua fasilitas yang mendukung agar sarana pariwisata dapat hidup dan berkembang serta dapat memberikan pelayanan pada wisatawan guna memenuhi kebutuhan mereka yang beranekaragam, antara lain :

1. Prasarana perhubungan,seperti jaringan jalan raya dan jaringan kereta api, bandar udara, pelabuhan laut, terminal angkutan darat dan stasiun kereta api.

2. Instalasi tenaga listrik dan instalasi perjernihan air bersih.

3. Sistem pengairan untuk kepentingan pertanian, perternakan, dan perkebunan.

4. Sistem perbankan dan moneter.

5. Sistem telekomunikasi, seperti telephone, internet,pos, televise, dan radio.

6. Pelayanan kesehatan dan keamanan. 


\section{PUBLICIANA : JURNAL ILMU SOSIAL DAN ILMU POLITIK \\ VOLUME 14, NO 02}

ISSN : 1979 - 0295 / E-ISSN : 2502 - 7336

7. Prasarana kesehatan seperti rumah sakit dan puskesmas

8. Prasarana pendidikan, keamanan, liburan.(Pramana,2018:56-57)

\section{METODE PENELITIAN}

Pendekatan penelitian yang dipilih dan dipakai oleh peneliti adalah tipe penelitian deskriptif dengan menggunakan pendekatan kualitatif.Dalam hal ini peneliti ingin memecahkan masalah dengan menggambarkan atau melukiskan keadaan objek penelitian pada saat sekarang berdasarkan fakta-fakta yang ada dan dideskripsikan dalam bentuk katakata dan bahasa yang diperoleh dari observasi, wawancara,dokumen,serta studi kepustakaan yang berkaitan dengan Dampak pembentukan kelompok sadar wisata (POKDARWIS) bagi pengembangan tujuan wisata pantai gemah Kecamatan Besuki Kabupaten Tulungagung.(Purnawati, 2020).

Data primer penelitian ini diperoleh dari wawancara, dokumentasi dan juga catatan lapangan yang diambil peneliti selama penelitian. Sedangkan data sekunder adalah dokumendokumen dari arsip yang ada kaitannya dengan pembentukan kelompok sadar wisata (POKDARWIS) bagi pengembangan tujuan wisata pantai Gemah kecamatan Besuki,Kabupaten Tulungagung. Teknik pengumpulan data dengan cara observasi non partisipatif, wawancara dengan pengurus pokdarwis "lejar Misuwur", pelaku usaha di pantai gemah dan pengunjung dan dokumentasi.

\section{HASIL DAN PEMBAHASAN}

Pantai Gemah merupakan Pantai yang terletak di pesisir selatan Kabupaten Tulungagung berada di Desa Keboireng Kecamatan Besuki, daya tarik pantai gemah mulai terdengar oleh masyarakat dengan terbangunnya Jalur Lintas Selatan (JLS) sehingga akses menuju pantai Gemah terbuka dan mudah terjangkau dengan kondisi jalan yang mulus. Kawasan Pantai Genah ditumbuhi oleh pohon Cemara udang sehingga menambah kesejukan pantai tersebut. Hamparan pantai yang luas membuat daya tarik para wisatawan untuk melakukan atraksi wisata diantaranya bermain pasir dan air laut, bermain perahu wisata, bermain motor ATV,Motor Trail dan wahana Flying Fox ditepi pantai,Ada juga wahana berwisata seperti :perahu wisata,Banana Boat.

Kelompok Sadar Wisata Pantai Gemah Tulungagung dibentuk pada tahun 2016 silam dengan nama "Alam Asri" ketika Pemerintah Kabupaten Tulungagung dan Provinsi Jawa Timur resmi membuka Jalur Lintas Selatan (JLS) yang dalam perencanaan jalur tersebut akan menghubungkan Kabupaten Tulungagung dengan Kabupaten Trenggalek dan di sekitar JLS tersebut terdapat Potensi Wisata yang sangat luar biasa indah yaitu Pantai Gemah dan secara tidak langsung Pemerintah Desa Keboireng membentuk Kelompok Sadar Wisata "Alam Asri”, Namun seiring dengan berjalanya waktu terjadi perombakan susunan dan kepengurusan pada tahun 2019 kemarin, Pokdarwis resmi dirubah nama menjadi "Lejar Misuwur" yang bertugas untuk mengelola dan mengembangkan potensi yang dimiliki oleh Pantai Gemah sehingga lebih dikenal.

Selain hal tersebut, latar belakang terbentuknya Kelompok Sadar Wisata "Lejar Misuwur" berasal ketika Pemerintah Kabupaten Tulungagung dan Provinsi Jawa Timur resmi membuka Jalur Lintas Selatan (JLS) pada tahun 2016 silam yang semula Pokdarwis tersebut bernama "Alam Asri", Namun seiring dengan berjalanya waktu terjadi perombakan susunan dan kepengurusan pada tahun 2019 kemarin, Pokdarwis resmi dirubah nama menjadi "Lejar Misuwur" Namun Tugasnya tetap sama untuk 
mengelola dan memelihara Pantai Gemah Tulungagung. oleh masyarakat baik dalam skala Regional, Nasional,bahkan Internasional.

Kelompok sadar wisata merupakan salah satu lembaga yang mempunyai peran strategis dan penting dalam pengembangan Destinasi Wisata. Kelompok Sadar Wisata "Lejar Misuwur" merupakan lembaga yang mempunyai peran strategis dan penting dalam mengembangkan potensi pariwisata yang dimiliki Pantai Gemah, sehingga dapat mendorong pembangunan infrastruktur dan sarana prasarana pariwisata di Pantai Gemah Tulungagung.

Sarana dan prasarana memang hal yang penting dalam kegiatan kepariwisataan dan selalu di upgrade dalam setiap waktu,hal tersebut tentunya sesuai dengan yang dijelaskan oleh ketua kelompok sadar wisata "Lejar Misuwur" bapak Imam Rojikin,sebagai berikut :

"Kita menyediakan sarana dan prasarana yang memadai dan lengkap untuk para wisatawan yang berkunjung di Pantai Gemah,diantaranya lahan parkir yang luas,listrik,air,pos keamanan, pos informasi, Homestay, warung, masjid, penyewaan motor trail, penyewaan ATV, perahu wisata, flying fox,Gazebo,gardu Pandang.dll. Tujuanya Sarana dan prasarana yang ada di pantai Gemah tersebut dapat memenuhu setiap kebutuhan para wisatawan yang berkunjung,dan kita selalu membangun dan berupaya memelihara sarana dan prasarana tersebut" (wawancara tgl 19-06-2021,di Pantai Gemah).

Kelompok Sadar Wisata juga selalu berinovasi untuk membangun berbagai sarana dan prasarana tambahan yang dimana untuk mendukung proses pengembangan Pantai Gemah,hal tersebut telah disampaikan oleh mas wahyu selaku Sekertaris Kelompok Sadar Wisata "Lejar Misuwur",sebagai berikut :

"Nah,terkait pengembangan sarana dan prasarana kita juga membuat gardu pandang yang masih baru,yang kita pasang di setiap titik pantai,yang dimana berfungsi untuk kami memantau keadaan pantai dari atas. Nah terkait pembangunan kita juga mendapat bantuan dari pemerintah kabupaten namun jumlahnya hanya sedikit dan kebanyakan kita mengelola perolehan tiket untuk mengdakan pembangunan sarana dan prasarana di Pantai Gemah ini." (wawancara tgl 25-06-2021,di Pantai Gemah).

Pihak pengelola juga mengembangkan acara wisata yang lainya supaya dapat meningkatkan jumlah pengunjung di Pantai Gemah,Hal tersebut diungkapkan oleh mas Wahyu selaku Sekertaris Kelompok Sadar Wisata "Lejar Misuwur",sebagai berikut :

"selain acara tahunan grebeg suro,kita juga pernah menyelenggarakan acara festival layang-layang dan Paralayang dengan menampilkan kesenian lokal dan menampilkan musik dangdut yang digandrungi oleh para pengunjung,kami berupaya semaksimal mungkin untuk berinovasi, nah yang terbaru kita juga mengadakan acara Gelar Sadar Wisata yang bekerjasama dengan Duta Wisata Tulungagung,nah dalam acara tersebut kami menarik para wisatawan untuk menjaga kebersihan dengan suguhan musik yang menarik,sehingga banyak dari seluruh masyarakat yang ikut serta di dalamnya".(wawancara tgl 25-06-2021, di Pantai Gemah).

Dalam pengembanganya Kelompok Sadar Wisata sangat berpengaruh karena mempunyai peran yang strategis dan penting. Dampak Pembentukan Kelompok Sadar Wisata "Lejar Misuwur" dalam pengembangan potensi pariwisata di Pantai Gemah Tulungagung adalah sebagai berikut:

1) Potensi Pariwisata Pantai Gemah menjadi terkenal 
Kelompok Sadar Wisata merupakan salah satu lembaga yang berasal dari masyarakat yang mempunyai kepedulian, dan tanggung jawab serta berperan aktif sebagai penggerak pariwisata dan Sapta Pesona dalam mendorong pembangunan pariwisata sehingga dapat bermanfaat "Lejar Misuwur" juga mempunyai tanggung jawab sebagai penggerak pariwisata dan Sapta Pesona di Pantai Gemah Tulungagung.

Potensi pariwisata yang dimiliki oleh Pantai Gemah tentunya harus dikelola dan dikembangkan sehingga dapat menarik wisatawan dan dapat memasarkan Pantai Gemah supaya lebih dikenal baik dari skala regional dan Nasional,serta dapat mendorong kegiatan kepariwistaan dan dapat membuka lapangan pekerjaan dan secara tidak langsung dapat meningkatkan kesejahteraan masyarakat desa Keboireng kecamatan Besuki Kabupaten Tulungagung.

Tujuan dari dibentuknya Kelompok Sadar Wisata "Lejar Misuwur" adalah untuk mengangkat potensi pariwisata, membuka lapangan pekerjaan dan memberikan azaz manfaat bagi masyarakat di Desa Keboireng.Hal ini dikarenakan Desa Keboireng mempunyai potensi pariwisata yang sangat besar, maka dari itu Kelompok Sadar Wisata "Lejar Misuwur" bekerja keras untuk mengangkat, memperkenalkan, potensi pariwisata yang dimiliki Desa Keboireng sehingga dapat dikenal dan menjadi daerah tujuan wisata. Diharapkan dengan Dampak dibentuknya Kelompok Sadar Wisata "Lejar Misuwur" dalam pengembangan potensi pariwisata di Pantai Gemah dapat bermanfaat bagi masyarakat Desa Keboireng.

2) Pariwisata Pantai Gemah Terkelola dengan Baik

Salah satu peran dari Pokdarwis "Lejar Misuwur" adalah mengelola pariwisata di Pantai Gemah Tulungagung. Hal ini sesuai dengan yang dikatakan oleh Rosita Desiati bahwa Kelompok sadar wisata merupakan kelompok yang tumbuh atas inisiatif dan kemauan serta kesadaran masyarakat sendiri guna ikut berpartisipasi aktif memelihara dan melestarikan berbagai obyek dan daya tarik wisata dalam rangka meningkatkan pembangunan kepariwisataan di daerah. Kelompok sadar wisata sebagai pengelola terselenggaranya desa wisata mampu mengoptimalkan pengembangan wisata. (Rosita Desiati, 2013: 36).

Upaya pihak pengelola yaitu kelompok Sadar Wisata "Lejar Misuwur" untuk menjaga kebersihan pantai Gemah sudah sangat baik terbukti dengan dibentuknya Tim kebersihan dan solidnya semua Anggota untuk membersihkan Pantai,Namun masih kurangnya kessdaran Masyarakat/Pengunjung untuk menjaga kebersihan masih kurang,hal tersebut dibuktikan masih banyaknya sampah yang berserakan padahal di pesisir pantai sudah tersedia Tempat Sampah.dalam hal tersebut pengelola sudah melakukan berbagai macam upaya untuk meningkatkan kesadaran Pengunjung supaya tetap menjaga kebersihan dengan cara memasang tulisan-tulisan peringatan.

Dengan adanya pantai Gemah berpengaruh sangat besar terhadap peningkatan taraf perekonomian masyarakat sekitar. Mulai dari pengelola,Pelaku usaha,Penyewa Tikar,Motor Trail,ATV,Dll. Diambil dari Masyarakat Desa Keboireng. Yang dulunya cuma bisa mengandalkan hasil kebun dari pembukaan lahan secara illegal sekarang dapat meningkatkan perekonomian.Secara tidak langsung dapat meningkatkan kesejahteraan masyarakat sekitar dengan dibuktikan banyaknya generasi muda yang melanjutkan pendidikanya di tingkat lebih tinggi. 
3) Peningkatan Pengetahuan dan Keterampilan SDM Anggota dan Masyarakat sekitar tentang kepariwisataan.

Dengan Dibentuknya Kelompok Sadar Wisata "Lejar Misuwur" sebagai lembaga penggerak pariwisata tidak hanya melakukan pengelolaan pariwisata di Kawasan Pantai Gemah Tulungagung. Kelompok Sadar Wisata "Lejar Misuwur" mempunyai tanggung jawab untuk memberikan pemahaman kepariwisataan kepada anggotanya dan masyarakat di Kawasan Pantai Gemah Tulungagung.

Salah satu tugas dari Kelompok Sadar Wisata "Lejar Misuwur" dalam pengembangan potensi pariwisata yaitu melakukan kegiatan peningkatan pengetahuan dan kertampilan terhadap anggota dan masyarakat sehingga dapat mendorong pengembangan pariwisata di Pantai Gemah sesuai kegiatan kelompok sadar wisata dalam buku panduan kelompok sadar wisata yang diterbitkan oleh pemerintah.

4) Terjalin Kerja Sama dengan stakeholder dan Organisasi lain dalam mengembangkan potensi wisata di Pantai Gemah

Kegiatan pariwisata tidak akan berjalan tanpa adanya sinergitas antara stakeholder atau para pemangku kepentingan. Oleh karena itu Kelompok Sadar Wisata "Lejar Misuwur" bekerja sama dengan beberapa lembaga-lembaga lain atau organisasi masyarakat. Kelompok Sadar Wisata "Lejar Misuwur" menjalin kerjasama dengan Pemerintah Kabupaten Tulungagung melalui Dinas Kebudayaan dan Pariwisata, Dinas Kelautan,Dinas Koperasi dan UKM, Dinas Lingkungan Hidup,Perum Perhutani, LMDH (Lembaga Masyarakat Desa Hutan) /Pokdarwis/Desa dan lembaga Organisasi Non Pemerintah.

Dalam Pengelolaan objek wisata Pantai gemah Kelompok Sadar Wisata "Lejar Misuwur" juga bekerjasama dengan organisasi non Pemerintah, Karang taruna, Komunitas Pecinta, pemilik Homestay, Kelompok Pedagang, kelompok Kesenian lokal, Organisasi Pemuda. Melalui program kerjasama dengan kelompokkelompok atau organisasi lainnya ini, semua elemen masyarakat dapat berpartisipasi secara aktif sehingga pengembangan potensi kepariwisataan dapat tercapai dengan baik.

Selain dampak pembentukan Pokdarwis untuk menarik minat wisatawan di atas ternyata masih memiliki faktor pendukung dan penghambat di dalam pengembangan pariwisata di pantai Gemah. Faktor pendukungnya antara lain adalah sebagai berikut :

1) Sumber Daya Alam dan Daya Tarik Wisata

Sumber Daya Alam yang melimpah yang dimiliki Pantai Gemah merupakan potensi pariwisata yang besar. Dimana wisatawan dapat melihat keindahan Jalur Lintas Selatan (JLS) dan Para pengunjung bisa menikmati keindahan Pantai Gemah dari Ketinggian sebelum memasuki wilayah pantai,selain itu dipantai Gemah juga terdapat pohon cemara yang sangat rindang dan selain itu pantai Gemah memiliki garis pantai yang sangat panjang ditambah dengan pasir pantai yang berwarna coklat,tentunya menambah daya tarik wisata.

2) Sumber Daya Manusia

Sumber daya manusia merupakan salah satu kunci pembangunan dan pengembangan suatu daerah. Apabila kualitas Sumber daya manusia bagus, maka pembangunan dan pengembangan pariwisata di suatu daerah juga akan maju dan berkembang dengan baik. Salah satu upaya yang dilakukan untuk meningkatkan kualitas sumber daya yang dimiliki, maka Kelompok Sadar Wisata "Lejar Misuwur" melalui pelatihan terkait dengan pariwisata kepada anggotanya. Oleh karena itu Kelompok Sadar Wisata "Lejar Misuwur" 
melakukan program- program pelatihan terkait dengan pariwisata, seperti pelayanan wisatawan, pemandu outbond, untuk meningkatkan wawasan dan ketrampilan para anggota dalam mengelola Pantai Gemah.

Dalam pengelolaan dan pengembang desa wisata Kelompok Sadar Wisata "Lejar Misuwur" mengedepankan aspek hospitality- nya. Hospitality merupakan keramah tamahan terkait dengan aktivitas pelayanan atau penyediaan kebutuhan wisatawan selama berada di obyek wisata atau daerah wisata tertentu. Dimana sebuah pelayanan diberikan dengan keramah tamahan, etika yang baik, bahasa tubuh, perilaku yang menyenangkan kepada wisatawan.

3) Sarana dan Prasarana yang Memadai

Sarana dan Prasarana merupakan hal yang paling mendukung terhadap berkembangnya suatu destinasi wisata,begitu juga di pantai Gemah Tulungagung terdapat beberapa Sarana dan prasarana yang mendukung terselenggaranya kegiatan Wisata.

Kelompok Sadar Wisata "Lejar Misuwur" berperan aktif dalam memenuhu Sarana dan Prasarana di Pantai Gemah,supaya dapat menarik lebih banyak lagi Pengunjung. Sarana dan prasarana yang ada di pantai Gemah cukup lengkap mulai dari lahan parkir yang luas,listrik,air,pos keamanan, pos informasi, Homestay, warung, masjid, penyewaan motor trail, penyewaan ATV, perahu wisata, flying fox,Gazebo,gardu Pandang.dll. Tujuanya Sarana dan prasarana yang ada di pantai Gemah tersebut dapat memenuhu setiap kebutuhan para wisatawan yang berkunjung.

Sedangkan faktor penghambatnya adalah sebagai berikut :

1) Kurangnya Dana untuk Pengembangan

Dalam perencanaan pengembangan pantai Gemah anggaran yang diusulkan oleh Dinas Pariwisata tergantung pada prioritas pembangunan dan kemampuan anggaran Kabupaten Tulungagung. Kelemahan dalam PKS (perjanjian kerja sama) yang setiap tahun diperbaharui menyebabkan minat investor untuk berinvestasi di pantai gemah itu kurang Dan untuk hal tersebut Kelompok Sadar wisata "Lejar Misuwur" kebanyakan hanya mengelola perolehan tiket masuk untuk dana Pengembangan Pantai Gemah.

2) Kurangnya kesadaran dan Pemahaman Sapta Pesona Masyarakat Sekitar Kurangnya kesadaran dan penerapan mengenai Sapta Pesona menjadi hambatan bagi Kelompok Sadar Wisata "Lejar Misuwur" dalam mengembangkan potensi pariwisata dan mewujudkan Pantai Gemah sebagai daerah tujuan wisata. Hambatan tersebut berasal dari beberapa warga, dimana warga kurang peduli terhadap keindahan dan kebersihan lingkungan. Keindahan dan kebersihan lingkungan merupakan sebagian unsur dari Sapta Pesona. Sapta Pesona sendiri harus diwujudkan dalam sebuah destinasi wisata.

3) Keamanan untuk Para Wisatawan

Keamanan merupakan hal yang terpenting diciptakan di destinasi wisata,sehingga para pengunjung tidak ada perasaan cemas jika mengunjungi destinasi wisata. Termasuk yang diterapkan di pantai Gemah Tulungagung yang menerapkan keamanan terjamin disetiap pengunjung. untuk mencegah tindak kriminalitas yang ada di pantai Gemah pihak pengelola yaitu Pokdarwis 
"Lejar Misuwur" bekerja sama dengan pihak kepolisian. Hal-hal negatif yang timbul akibat aktifitas seperti mabuk-mabukan atau mengkonsumsi narkoba itu selalu dicegah oleh kepolisian khususnya polsek Besuki.

\section{KESIMPULAN}

Dengan adanya Kelompok Sadar Wisata "Lejar Misuwur" dampak yang bisa dilihat dan dirasakan oleh masyarakat setempat adalah pantai gemah menjadi semakin dikenal luas . Hal ini karena selain melakukan pembenahan pada aspek pengelolaan juga membenahi sarana dan prasarana di pantai Gemah. Selain itu, dengan adanya Pokdarwis juga membawa dampak masyarakat setempat mempunyai kesadaran untuk ikut berprtisipasi dan berinovasi sehingga ada nilai lebih yang di dapat wisatawan apabila berkunjung ke pantai Gemah.Sehingga bisa dikatakan bahwa dibentuknya Kelompok Sadar Wisata "Lejar Misuwur" dalam hal pengembangan potensi pariwisata di Pantai Gemah membawa dampak yang cukup bagus terhadap pengembangan daerah wisata pantai Gemah.

Pembentukan Pokdarwis ini memang tidak serta merta membuat pantai gemah menjadi salah satu destinasi wisata favorit karena masih ada beberapa faktor yang menghambat seperti masih kurangnya kesadaran masyarakat terhadap sapta pesona dan keamanan pengunjung belum terjamin sepenuhnya. Akan tetapi, kekayaan alam yang indah dan menarik merupakan faktor yang mendorong wisatawan untuk tetap datang ke pantai gemah.

\section{DAFTAR PUSTAKA}

Anarta, R. (2019). Pengembangan Mining Tourism Di Kawasan Pertambangan Sawahlunto.

Sosiohumaniora, 21(2), 184-193. https://doi.org/10.24198/sosiohumaniora.v21i2.11236

Arjana, I Gusti Bagus. 2016. Geografi Pariwisata dan Ekonomi Kreatif.

Jakarta: Rajawali Pers.

Burhan Bungin. (2015) Komunikasi Pariwisata Pemasaran dan Brand Destinasi Jakarta:

Prenadamedia Group

Bungaran Antonius Simanjuntak, dkk, (2017) Sejarah Pariwisata: Menuju Perkembangan

Pariwisata Indonesia, Jakarta: Yayasan Pustaka Obor Indonesia

Junaid, I., Salam, N., \& Salim, M. A. M. (2019). Developing homestay to support community-based tourism. Masyarakat, Kebudayaan Dan Politik, 32(4), 390. https://doi.org/10.20473/mkp.v32i42019.390-398

Purnawati, L. (2020). Peranan Pemerintah Desa dalam Menangani Konflik Peternakan Ayam Broiler di Desa Pucanglaban Kabupaten Tulungagung. Nakhoda: Jurnal Ilmu Pemerintahan, 19(2), 229-243. https://doi.org/10.35967/njip.v19i2.117

Rohyani, I. S., Nursalim, I., \& Arminy, N. S. (2019). Pegembangan Potensi Wisata Melalui Optimalisasi Peran Kelompok Sadar Wisata (Pokdarwis) Desa Arjangka. Abdi Insani, 6(3), 332-339. https://doi.org/10.29303/abdiinsani.v6i3.254

Rosita Desiati. (2013). Pemberdayaan Masyarakat Melalui Pengelolaan Program Desa Wisata Oleh Kelompok Sadar Wisata Krebet Binangun di Krebet, Sendang Sari, Pajangan, Bantul, Yogyakarta. Skripsi S1. UNY.

Shofwan Hanief dan Dian Pramana, (2018),Pengembangan Bisnis

Pariwisata Dengan Media Sistem Informasi, Yogyakarta:Andi

Sugiyono. (2017). Metode Penelitian Kualitatif. Bandung: Alfabeta

Sukiman, (2012), Pengembangan Media Pembelajaran, Yogyakartra: PT. Pustaka Insan Madani

Tengah, S. L. (2020). PERANAN POKDARWIS BATU REJENG UNTUK 
PUBLICIANA : JURNAL ILMU SOSIAL DAN ILMU POLITIK

VOLUME 14, NO 02

ISSN : 1979 - 0295 / E-ISSN : 2502 - 7336

MENGEMBANGKAN DESA SENTILING LOMBOK TENGAH. 1(1).

Wijaya, S. A., Zulkarnain, \& Sopingi. (2016). Proses Belajar Kelompok Sadar Wisata (

Pokdarwis ) Dalam Pengembangan Kampoeng Ekowisata. Jurnal Pendidikan

Nonformal, XI(2), 88-96. 